Volume 25

February 2013

\title{
The Second Amendment and Gun Control
}

Erwin Chemerinsky

Follow this and additional works at: https://digitalcommons.tourolaw.edu/lawreview

Part of the Constitutional Law Commons, and the Second Amendment Commons

\section{Recommended Citation}

Chemerinsky, Erwin (2013) "The Second Amendment and Gun Control," Touro Law Review. Vol. 25: No. 2, Article 9.

Available at: https://digitalcommons.tourolaw.edu/lawreview/vol25/iss2/9

This Article is brought to you for free and open access by Digital Commons @ Touro Law Center. It has been accepted for inclusion in Touro Law Review by an authorized editor of Digital Commons @ Touro Law Center. For more information, please contact Iross@tourolaw.edu. 


\title{
The SECONd Amendment ANd Gun ConTrol
}

\author{
Erwin Chemerinsk*
}

The second amendment case decided this term was District of Columbia v. Heller. ${ }^{1}$ Thirty-two years ago the District of Columbia adopted a law prohibiting private possession and ownership of handguns as well as imposed strict regulations on the ownership of long guns. ${ }^{2}$ A year ago in 2007, the United States Court of Appeals for the District of Columbia Circuit, in a two-to-one decision, declared the District of Columbia law unconstitutional for violating the Second Amendment. ${ }^{3}$ The Supreme Court subsequently granted certiorari, and on June 26, the last day of the term, in a five-to-four decision, declared the District of Columbia law unconstitutional. ${ }^{4}$ Not surprisingly, the Court was divided along ideological lines. Again, not surprisingly, Anthony Kennedy was in the majority. ${ }^{5}$

Justice Scalia wrote the opinion for the Court, joined by Chief

\footnotetext{
- Dean and Distinguished Professor of Law, University of California, Irvine School of Law. This Article is based on a presentation given at the Practising Law Institute's Tenth Annual Supreme Court Review Program in New York, New York.

128 S. Ct. 2783 (2008).

2 D.C. CoDE ANN. § 7-2502.01 (2008).

3 Heller, 128 S. Ct. at 2788. See also Parker v. District of Columbia, 478 F.3d 370, 395, 399-401 (D.C. Cir. 2007).

${ }^{4} I d$. at 2821-22 (holding "the District's ban on handgun possession in the home violates the Second Amendment, as does its prohibition against rendering any lawful firearm in the home operable for the purpose of immediate self defense").

5 Id. at 2786; see also Lisa K. Parshall, Embracing the Living Constitution: Justice Anthony M. Kennedy's Move Away From a Conservative Methodology of Constitutional Interpretation, 30 N.C. CENT. L. REV. 25, 25-27 (2007). This Article outlines and analyzes the critical swing vote role Justice Kennedy has played in the Court and expresses his allegiance to Justice Scalia as well as to the fundamental principles of the Constitution.
} 
Justice Roberts, and Justices Kennedy, Thomas, and Alito. ${ }^{6}$ Justice Scalia wrote the only opinion for the majority. ${ }^{7}$ There were no concurring opinions. There were two dissents written by Justices Stevens and Breyer, with which Justices Souter and Ginsburg joined. ${ }^{8}$

Both the majority and the dissent were very long; both were very thorough. I think they disagree about three things. They disagree about what the text of the Second Amendment means; they disagree about what the original meaning of the Second Amendment was; and they disagree about what history teaches. I want to discuss each of these and identify the open questions to be litigated.

First, there is a disagreement over the text of the Second Amendment. There has long been this disagreement. The Second Amendment says, "[a] well regulated Militia, being necessary to the security of a free State, the right of the people to keep and bear Arms, shall not be infringed." Those who favor gun rights focus on the second halt of the Second Amendment, saying "the right of the people to keep and bear Arms, shall not be infringed."10 Those in favor of gun control focus on the former clause of the Second Amendment, saying it is really all about the right to have guns for purposes of mili-

${ }^{6}$ Heller, 128 S. Ct. at 2786.

7 Id. at 2787.

8 Id. at $2822,2847$.

9 U.S. CONST. amend. II.

${ }^{10}$ Id. See also Robert Hardaway, Elizabeth Gormley \& Bryan Taylor, The Inconvenient Militia Clause of the Second Amendment: Why the Supreme Court Declines to Resolve the Debate Over the Right to Bear Arms, 16 ST. JoHN's J. LEGAL COMMENT. 41, 57 (2002); David E. Johnson, Note, Taking a Second Look at the Second Amendment and Modern Gun Control Laws, 86 KY. L.J. 197, 198 (1997); Ronald S. Resnick, Private Arms as the Palladium of Liberty: The Meaning of the Second Amendment, 77 U. DET. MERCY L. REV. 1, 3 (1999). 
tia service, therefore that is the only right that is protected. ${ }^{11}$

Justice Scalia, writing for the Court, said "the first half of the Second Amendment is the prefatory clause and the second half is the operative clause," and that a prefatory clause cannot negate the meaning of an operative clause. ${ }^{12} \mathrm{He}$ said besides, he thought all ablebodied men were part of the militia; therefore the militia was a synonym. ${ }^{13}$ He talked about the language, the people, and the context of the Constitution. He said the text of the Second Amendment supports the gun right's position. ${ }^{14}$ Justice Stevens disagreed. He said the militia was not referring to everybody, and, of course, women could not serve in the militia, and in southern states, African Americans could not serve in the militia. ${ }^{15}$ Therefore, the word "militia" was not inclusive of everybody.

Justice Stevens in his dissent said the phrase "keep and bear arms" had an understood meaning at the time. It was all about having arms for military service. ${ }^{16}$ He said that there is not a prefatory clause and operative clause; there is one Second Amendment. ${ }^{17}$

Second, there was a disagreement over the original meaning

11 Johnson, supra note 10 , at 198; see Resnick, supra note 10 , at 3 .

12 Erwin Chemerinsky, The Heller Decision: Conservative Activism and its Aftermath, CATO-UNBOUND.ORG, http://www.cato-unbound.org/2008/07/25/erwin-chemerinsky/theheller-decision-conservative-activism-and-its-aftermath/; see also Heller, $128 \mathrm{~S}$. Ct. at 2789.

13 Heller, $128 \mathrm{~S}$. Ct. at 2800 ("This is fully consistent with the ordinary definition of the militia as all able-bodied men.").

14 Id. at 2797 ("The very text of the Second Amendment implicitly recognizes the preexistence of the right and declares only that it 'shall not be infringed." ").

15 Id. at 2808 n.21, 2837 n.29 (Stevens, J., dissenting).

16 Id. at 2826 ("[T] he Framers' single-minded focus . . was on military uses of firearms, which they viewed in the context of service in state militias.").

17 Id. at 2824-31. "Such text should not be treated as mere surplusage, for "[i]t cannot be presumed that any clause in the constitution is intended to be without effect." "Id. at 2826 (citing Marbury v. Madison, 5 U.S. (1 Cranch) 137, 174 (1803)). 
of the Constitution. Justice Scalia said it was the original meaning of the Constitution to protect the right of individuals to have guns, particularly for purposes of self-defense, especially in the context of their homes; the District of Columbia law would prohibit this. ${ }^{18} \mathrm{He}$ surveyed the laws that existed in 1791, the time the Second Amendment was adopted. ${ }^{19}$ The fact that every state had provisions in its state constitution to safeguard the right of individuals to have guns supports this view as the original meaning of the Second Amendment.

Justice Stevens, however, took a very different view of the original meaning. He said James Madison, in the initial first draft of the Second Amendment, had a provision that exempted people from militia service if they were conscientious objectors. This, he said, was a clear indication that the meaning of the Second Amendment was all about militia service, and not a general right of the people to have guns. $^{20}$ He said the framers had a great fear of large standing armies, and, accordingly, you have to understand the Second Amendment as protecting the right to have guns for militia service. ${ }^{21}$

The justices also disagreed over history. Justice Scalia traced history through the nineteenth and early twentieth centuries, talked

18 Id. at 2817-18 (majority opinion) ("The handgun ban amounts to a prohibition of an entire class of 'arms' that is overwhelmingly chosen by American society for that lawful purpose. The prohibition extends, moreover, to the home, where the need for defense of self, family, and property is most acute.").

19 See generally id. at 2791-98.

${ }^{20}$ Id. at 2835-36 (Stevens, J., dissenting) ("The ultimate removal of the clause [excluded in the final draft] ... only serves to confirm the purpose of the Amendment- to protect against congressional disarmament, by whatever means, of the States' militias.").

${ }_{21}$ Id. at 2840 ("An important check on that danger . . . was a 'well-regulated militia,' for which ... arms would have to be kept and, when necessary, borne."). 
about the leading commentators at the time, state courts, and concluded that throughout history the Second Amendment was about an individual's right to have guns apart from the militia service. ${ }^{22}$ Justice Stevens said that throughout American history, from 1791 until June 26, 2008, there was no Supreme Court decision that had ever interpreted the Second Amendment as creating a right of individuals to have guns apart from militia service. No Supreme Court cases in American history have ever found any law to violate the Second Amendment. ${ }^{23}$ He relied on precedent, particularly voters in a 1939 decision United States $v$. Miller. ${ }^{24}$ In Miller, the Supreme Court rejected a Second Amendment challenge to a federal law that prohibited sawed-off shotguns. ${ }^{25}$ The Supreme Court said the Second Amendment has to be understood in terms of its language, and since sawed-off shotguns were not weapons used in militia service, they are not protected by the Second Amendment. ${ }^{26}$ Justice Stevens said this language is a clear indication that the Court in Miller took the view that the Second Amendment only took to safeguard the right to have guns for purposes of militia service. ${ }^{27}$

I think there are two key questions to be litigated after Heller. The first question is what is the standard of review and level of scru-

\footnotetext{
22 Heller, 128 S. Ct. at 2799 (majority opinion).

23 Id. at 2822-24, 2844 (Stevens, J., dissenting).

24 Id. at 2823; see United States v. Miller, 307 U.S. 174 (1939).

25 Miller, 307 U.S. at 177 (holding that without evidence of a relationship between possession of a sawed off shotgun and "the efficiency of a well regulated militia," the Court could not say that the Second Amendment protected an individual's "right to keep and bear" the weapon).

${ }^{26}$ Id. at 178 .

${ }^{27}$ Heller, 128 S. Ct. at 2823 (Stevens, J., dissenting) (" [I]t does not curtail the Legislature's power to regulate the nonmilitary use and ownership of weapons.").
} 
tiny that lower courts are to use when there are challenges to laws that regulate guns? In constitutional litigation, the outcome so often depends on the level of scrutiny used. Nowhere does the Court answer that question. There is one sentence in Justice Scalia's majority opinion which says that under any standard of review the District of Columbia law would be unconstitutional. ${ }^{28}$ I think Justice Breyer does an excellent job of showing that is not so. ${ }^{29}$ At least under rational basis review, the District of Columbia law would be upheld.

Justice Breyer devotes his dissenting opinion to the standard of review question. He points out that forty-two states have state constitutional provisions that create a right for individuals to have guns, and in those forty-two states, regulations are allowed so long as they are reasonable. ${ }^{30}$ Justice Breyer explains that the District of Columbia has a legitimate objective in decreasing gun violence. $\mathrm{He}$ acknowledges these studies are disputed, but says it is enough for rational basis review. ${ }^{31}$ If it is not rational basis review, what is the level of scrutiny to be used? I think the fact that the Supreme Court does not specify the level of scrutiny is an open invitation to litigation. Think of all of the federal laws that involve provisions that regulate guns. Anyone who is subjected to criminal prosecution, or

28 Id. at 2817-18 (majority opinion) ("Under any of the standards of scrutiny . . . banning [handguns for protection] from the home ... would fail constitutional muster.").

29 Id. at 2851 (Breyer, J., dissenting) ("It certainly would not be unconstitutional under . . . a 'rational basis' standard, which requires a court to uphold regulation so long as it bears a 'rational relationship' to a 'legitimate governmental purpose.' ").

30 Id. at 2853.

31 Id. at 2851. ("The law at issue . . at least bears a 'rational relationship' to that 'legitimate' life-saving objective." ). "[T]he studies ... are controversial. But they do not by themselves show that those judgments are incorrect; nor do they demonstrate a consensus, academic or otherwise, supporting that conclusion." Id. at 2859. 
has to deal with the administrative regulation of guns, has every reason to bring a challenge.

Now, Justice Scalia made clear that the Second Amendment right to bear arms does not create an absolute right as he explained the government can still regulate where people have guns; i.e. keeping guns from being in airports and schools. ${ }^{32}$ Additionally, he said the government can still regulate who has guns. ${ }^{33}$ For example, the government can keep people with felony convictions from having guns, but he does not specify what the level of scrutiny is, which is why anybody who is subjected to prosecution regulation with regard to guns has every reason to bring a challenge and see what happens. I think what the lower courts are going to have to struggle with is what is the level of scrutiny.

The second question I think is less likely to be of long-term significance, but it will be important in the short term: Does the Second Amendment apply to state and local governments? When the Bill of Rights was adopted it was thought to apply only to the federal government. It was only in the late nineteenth century and early in the twentieth century, that the Supreme Court said the Bill of Rights applies to state and local governments through its incorporation of the Due Process Clause of the Fourteenth Amendment. The Supreme Court never said all of the Bill of Rights provisions are incorporated. There are several provisions, five altogether, where the Court never found them to apply to state and local governments. One of these is the Second Amendment. The Heller case involves part of the federal

${ }^{32}$ Heller, 128 S. Ct. at 2816-17 (majority opinion). 
government, so the Court did not have to reach the incorporation question.

The day after the case came down on June 27,2008 , the National Rifle Association brought challenges in federal court to the San Francisco and to the Chicago gun control ordinances, clearly wanting to present the issue of whether or not the Second Amendment applies to state and local governments? ${ }^{34}$ My intuition is that the Court will say yes. Once they find it is an individual right, then I think it would logically follow that the Court will say it applies to state and local governments. But since it was a five-four decision, there is always the chance that one of the five might draw some distinction between state and local government. I think the first question, the level of review, will be open and litigated for a long time to come. The second question will more likely be resolved sometime soon.

\footnotetext{
${ }^{33}$ Id.

34 AP, NRA Targets San Francisco, Chicago, CBS News, June 27, 2008, http:// www.cbsnews.com/stories/2008/06/27/national/printable4216152.shtml ("The National Rifle Association sued the city of San Francisco on Friday to overturn its handgun ban in public housing.").
} 